\title{
KEKERASAN DALAM RUMAH TANGGA; \\ SUATU TINJAUAN INTERAKSIONIS
}

Fakhri Usmita, M.Krim

\begin{abstract}
Domestic violence that is unique violence, especially cause offender and the victim are closely or have a bond. Using literature review especially with symbolic interactionist approach, this article would like to explain simply why someone who is "close", or (initially) loves each other, can do violence, even that is considered cruel, inhuman just because of trivial things. In an interactionist view, domestic violence can occur because of the interpretation of the actor against the situation he faces. The actor defines the situation he faces, and decides to be resolved by using force.
\end{abstract}

Keywords: Domestic Violence, Interpersonal Relationship, Interactionist.

\section{Pendahuluan}

Kekerasan dalam rumah tangga (KDRT) masih dianggap sebagai urusan pribadi, dan tabu untuk diceritakan kepada pihak lain. Sehingga fenomena ini seakan hanya gosip, bahkan menjadi mitos (lihat Gelles, 1985). Dibanding disiplin ilmu lainnya, sosiologi sendiri dinilai terlambat dalam mengkaji fenomena kekerasan dalam rumah tangga. Kekerasan dalam rumah tangga baru menjadi perhatian para sosilog pada tahun 1970an, sementara bidang ilmu medis atau pediatric misalnya, telah mencatat adanya kasus cedera tulang pada anak akibat perlakuan anggota keluarganya pada tahun 1946 (Gelles, 1985; 347).
Di kalangan masyarakat umum, kekerasan dalam rumah tangga masih dianggap sebagai urusan "kamar" pribadi (privasi), serta bukan suatu hal yang serius. Sehingga pihak luar tidak perlu turut campur di dalamnya. Di sisi lain, fenomena kekerasan ini perlu memperoleh perhatian khusus dan serius, karena tidak jarang kekerasan ini dapat mengakibatkan cedera fisik, berdampak pada kesehatan mental, perubahan prilaku, komplikasi kehamilan, dan kondisi kesehatan lainnya, dan umumnya kasus-kasus ini banyak yang tidak terungkap atau diketahui.

Kekerasan dalam rumah tangga termasuk kelompok kekerasan yang unik, dimana pelaku dan korban, tidak 
saja telah saling kenal, tetapi juga memiliki ikatan keluarga, bahkan (awalnya) saling mencintai. Namun tidak jarang, kekerasan yang terjadi berdampak luar biasa, menyebabkan cedera fisik yang fatal, bahkan kematian dengan cara atau proses tidak manusiawi.

Dalam arti umum, kekerasan menunjukkan semua tipe-tipe dari perilaku baik itu berupa ancaman atau suatu perbuatan yang menyebabkan atau dengan sengaja menyebabkan kerugian atau kerusakan hak milik, luka atau matinya seseorang.

Secara khusus, penyebutan korban kekerasan dalam rumah tangga lebih ditujukan kepada perempuan. Hal ini seperti termaktub dalam Pasal 1 Undangundang Nomor 23 Tahun 2004, dimana disebutkan bahwa kekerasan dalam rumah tangga adalah setiap perbuatan terhadap seseorang terutama perempuan, yang berakibat timbulnya kesengsaraan atau penderitaan secara fisik, seksual, psikologis, dan/atau penelantaran rumah tangga termasuk ancaman untuk melakukan perbuatan, pemaksaan, atau perampasan kemerdekaan secara melawan hukum dalam lingkup rumah tangga.
Meski tidak selalu korban kekerasan dalam rumah tangga adalah perempuan, tapi pengkhususan korban kekerasan dalam rumah tangga adalah perempuan sebenarnya masuk akal bila mengingat sebagian besar kasus kekerasan dalam rumah tangga dilakukan oleh laki-laki, dan korbannya sebagian besar adalah perempuan (bukan laki-laki).

Adapun lingkup pengertian rumah tangga berdasarkan Undang-Undang No. 23 Tahun 2004 meliputi: a) suami-istri, dan anak; b) orang-orang yang mempunyai hubungan keluarga dengan orang sebagaimana dimaksud pada huruf a karena hubungan darah, perkawinan, persusuan, pengasuhan, dan perwalian, yang menetap dalam rumah tangga; dan/atau; c) orang yang bekerja membantu rumah tangga dan menetap dalam rumah tangga tersebut.

Kekerasan dalam rumah tangga termasuk dalam kekerasan yang unik, dimana pelaku dan korban adalah orang yang telah saling mengenal sebelum peristiwa kekerasan terjadi, dan seharusnya saling menyayangi. Ironisnya, kekerasan dalam rumah tangga tidak jarang berupa pembunuhan atau penganiayaan berat. Fenomena ini menunjukkan bahwa kekerasan dapat 
dilakukan oleh siapa saja, kepada siapa saja, dan dimana saja, termasuk di dalam rumah yaitu suatu tempat yang seharusnya menjadi tempat yang paling aman bagi seseorang.

Di Indonesia, kekerasan dalam rumah tangga juga menjadi perhatian terutama bagi aktifis-aktifis pejuang kesetaraan gender, hingga disahkannya undang-undang Nomor 23 Tahun 2004 tentang Penghapusan Kekerasan Dalam Rumah Tangga. Pengesahan undangundang ini tidak berarti perjuangan perwujudan kesetaraan gender dan penghapusan kekerasan dalam rumah tangga telah sampai pada titik akhir.
Pada kenyataannya, pemahaman masyarakat umum bahkan aparat penegak hukum tentang pentingnya penghapusan kekerasan dalam rumah tangga harus lebih ditingkatkan, sehingga penerapan undang-undang ini juga merupakan perjuangan tersendiri.

Pekanbaru sendiri selama tahun 2012-2016, tercatat 190 kasus kekerasan dalam rumah tangga, dimana Polsek Bukit Raya mencatat terbanyak sebanyak 50 kasus, disusul Tampan sebanyak 49 kasus. Sementara Polsek Senapelan belum belum ada catatan selama kurun waktu tersebut. Gambaran lebih lengkap tersaji pada table berikut:

Tabel 1. Kekerasan Dalam Rumah Tangga di Wilayah Poltabes Pekanbaru

\begin{tabular}{|l|r|r|r|r|r|r|}
\hline Polisi Sektor & $\mathbf{2 0 1 2}$ & $\mathbf{2 0 1 3}$ & $\mathbf{2 0 1 4}$ & $\mathbf{2 0 1 5}$ & $\mathbf{2 0 1 6}$ & Jumlah \\
\hline Bukit Raya & 15 & 9 & 11 & 11 & 4 & 50 \\
\hline Lima Puluh & 7 & 15 & 6 & 2 & 4 & 34 \\
\hline Pekanbaru Kota & 3 & 3 & 1 & 1 & 0 & 8 \\
\hline Rumbai & 2 & 4 & 4 & 1 & 8 & 19 \\
\hline Rumbai Pesisir & 5 & 1 & 3 & 1 & 0 & 10 \\
\hline Senapelan & 0 & 0 & 0 & 0 & 0 & 0 \\
\hline Sukajadi & 7 & 5 & 4 & 0 & 4 & 20 \\
\hline Tampan & 14 & 7 & 11 & 10 & 7 & 49 \\
\hline Pekanbaru & 53 & 44 & 40 & 26 & 27 & 190 \\
\hline
\end{tabular}

Sumber: Latif., Usmita., dan Novarizal, 2017.

Perkembangan kekerasan dalam rumah tangga di Pekanbaru selama lima tahun tersebut berfluktuasi, tertinggi terjadi pada tahun 2012 sebanyak 53 kasus, dan terendah pada tahun 2015 sebanyak 26 kasus. Khusus tahun 2016, setiap 324 jam 26 menit 39 detik terjadi satu tindak kekerasan rumah tangga di Kota Pekanbaru.

Secara statistik, terlihat gambaran menggembirakan dimana terdapat penurunan sekitar 50\% pada tahun 2016 
bila dibanding tahun 2012. Tatapi, angka-angka tersebut bukanlah gambaran utuh dari realitas kekerasan dalam rumah tangga yang ada. Pada kenyataannya, dimungkinkan kasus kekerasan dalam rumah tangga yang terjadi jauh lebih besar dari data tersebut. Hal tersebut dimungkinkan antara lain karena pencatatan oleh pihak terkait, atau bahkan keengganan korban untuk mengadukan apa yang mereka alami, rasakan, atau saksikan ke pihak berwajib. Selain itu, sumber data utama berasal dari kepolisian, karena sumber lain seperti rumah sakit misalnya, belum secara khusus mencatat suatu kasus sebagai kekerasan dalam rumah tangga. Selain itu, kekerasan dalam rumah tangga termasuk dalam kekerasan yang tidak mau dilaporkan (underreported crime). Bilapun ada yang dilaporkan, umumnya karena telah terjadi cedera atau insiden yang serius, sehingga angka kejahatan belumlah mencerminkan realita kejahatan kekerasan dalam rumah tangga yang ada di tengah masyarakat.

Terlepas dari besar atau kecilnya jumlah angka kekerasan dalam rumah tangga yang tercatat di kepolisian, fenomena kekerasan dalam rumah tangga harus disingkapi dan diupayakan pencegahannya.
Permasalahan kekerasan dalam rumah tangga penting untuk menjadi perhatian setiap kalangan, mengingat dampak yang dimunculkan oleh kekerasan ini dapat bersifat sistemik, memunculkan rantai kekerasan, terutama bila menyangkut anak, baik anak sebagai saksi, korban ataupun pelaku. Sebagai bentuk dari kejahatan, KDRT seharusnya menjadi tolok ukur utama tingkat kesejahteraan masyarakat. Karena langsung terkait dan dirasakan oleh unit atau institusi terkecil dalam masyarakat yaitu keluarga.

Selain menyebabkan kerugian secara fisik maupun mental, kekerasan dalam rumah tangga tidak jarang menimbulkan kerugain materiil yang tidak sedikit. National Crime Victimization survey (NCVS) mencatat dari Januari 1992 hingga Juni 1998, kerugian yang ditimbulkan akibat kekerasan dalam rumah tangga di Amerika Serikat sebesar US \$ 4,9 milyar. Sebagian besar biaya tersebut dikeluarkan untuk pengobatan korban akibat KDRT. Suatu besaran yang fantastis bahkan untuk negara sekelas Amerika Serikat, sehingga kita tidak dapat lagi menganggap remeh permasalahan ini (Davis, 2008; 17). 
Di sisi lain, terutama bagi anak, keluarga merupakan tempat pembelajaran pertama dan jembatanya dengan masyarakat. Oleh sebab itu, kondisi rumah tangga seharusnya diupayakan seoptimal mungkin tercapai kondisi ideal yang kondusif bagi tumbuh kembang anak, baik secara fisik, maupun mentalnya. Dan berlangsungnya kekerasan dalam rumah tangga menghalangi kondisi itu.

Gelles (1985) dalam penelitiannya terhadap 80 orang responden yang pernah mengalami kekerasan dalam rumah tangga menemukan hanya satu responden yang mengalami kekerasan sejak sebelum pernikahan dan berlanjut setelah pernikahan. Artinya hampir semua responden baru mengalami kekerasan setelah mereka terikat dalam ikatan pernikahan. Meski hasil peeilitian Gelles ini masih dapat diperdebatkan, namun temuan ini cukup menarik. Setidaknya tergambar adanya hubungan interaksi antar personal yang berubah setelah pernikahan. Memahami perubahan pola interaksi antar personal yang menjadi pencetus KDRT adalah langkah penting guna menemukan intervensi yang tepat, dan ini yang menjadi fokus utama artikel ini.
Kekerasan dan Kekerasan Dalam Rumah Tangga

\section{A. Kekerasan}

Awalnya, bahasan tentang kekerasan cenderung dikonotasikan dengan peperangan, atau suatu perbuatan yang dilakukan oleh suatu entitas kekuatan besar seperti negara. Dimana kekerasan merupakan jalan untuk menghapus keberadaan musuhnya, dan meski perang dunia kedua telah berakhir, namun peperangan telah membentuk karakter politik suatu negara (Clausewitz dalam Dodd, 2009; 20-21).

Arrent misalnya menyebutkan kekerasan adalah sesuatu yang diyakini (terutama oleh negara) untuk dapat mencapai tujuan (politis) mereka. Dimana kekerasan lebih sebagai bentuk penghukuman oleh mereka yang superior, dibanding jalan menuju kemenangan, ataupun perlombaan senjata. Dimana pemberian hukuman (pengentarjeraan) tersebut merupakan jalan untuk memelihara perdamaian (Arrent, 1970; 3-4).

Pada perkembangan selanjutnya, bahasan kekerasan tidak hanya pada konteks perang atau negara, tetapi telah masuk dalam ranah hubungan interpersonal. Hal ini didasari pada kenyataan, meski perang dunia dianggap 
telah usai, namun kekerasan masih terus berlangsung, dan korban masih berjatuhan. Sehingga definisi kekerasan umumnya difokuskan pada kondisi fisik akibat tindak kekerasan.

Meski belum ada definisi baku terkait apa itu kekerasan, tapi tetap diperlukan guna lebih memfokuskan pembahasan. Secara sederhana Kodir dan Mukarnawati mendefinisikan kekerasan sebagai suatu ketidaknyamanan yang dialami oleh seseorang (2008; 19). Pengertian ini dirasa masih sangat luas dan menimbulkan pertanyaan. Apakah semua ketidaknyamanan yang dialami seseorang dapat dikategorikan sebagai akibat dari kekerasan?

Rumusan lebih jelas ditawarkan oleh Gosita, dimana kekerasan dirumuskan sebagai "tindakan yang melawan hukum, dilakukan dengan sengaja oleh seseorang terhadap orang lain, baik untuk kepentingan sendiri atau orang lain, dan menimbulkan penderitaan mental, fisik, dan sosial” (Gosita, 1993: 44). Di sini terdapat dua titik tekan yang menjadi kata kunci dari pengertian kekerasan yang diajukan oleh Gosita, yaitu pada proses dan hasil. Pada tahap proses, kekerasan dianggap sebagai suatu perbuataan melanggar hukum, dan dilakukan secara sadar. Artinya, perbuatan tersebut telah dilarang oleh hukum yang berlaku, dan adanya sanksi kepada pelakunya. Penekanan lainnya pada hasil atau dampak dari perbuatan tersebut yaitu, kekerasan dapat menimbulkan derita secara fisik, mental, dan sosial. Artinya, dampak yang diderita akibat kekerasan tidak hanya sebatas secara fisik, tapi juga dapat secara mental, ataupun sosial.

Dalam konteks negara berkembang, kekerasan yang terjadi di tengah masyarakat (termasuk kekerasan dalam rumah tangga) tidak dapat dilepaskan dari peran negara. Dimana kejahatan kekerasan tersebut sangat terkait dengan kekerasan strutural yang terwujud sebagai pola hubungan dalam masyarakat akibat ketidakmerataan dan ketidakadilan penguasaan dan pengendalian sumber daya yang ada (Kusumah, 1982; 28).

Dalam konteks interpersonal, kekerasan didefinisikan sebagai perilaku oleh seseorang terhadap orang lain berupa ancaman dengan sengaja, mengisyaratkan akan menyerang secara fisik (gertakan), atau suatu tindakan nyata yang dapat menyebabkan cedera fisik bahkan kematian. Perilaku ini digolongkan dalam definisi agresif. 
Definisi tersebut mengecualikan tindakan atau perilaku manusia yang tanpa sengaja menyebabkan cedera fisik atau kematian misalnya kebijakan perusahaan yang menempatkan pekerjanya di daerah tercemar, penggunaan kekerasan oleh petugas penegak hukum, tewasnya atlit tinju saat pertandingan, dan lain sebagainya (Herrenkohl [editor], 2011; 15).

Secara garis besar, kekerasan berupa semua tipe-tipe dari perilaku baik itu berupa ancaman, atau suatu perbuatan yang menyebabkan atau dengan sengaja menyebabkan kerugian atau kerusakan hak milik, ketakutan, luka atau matinya seseorang. Artinya, kekerasan tidak hanya berupa suatu perbuatan berupa tindakan secara fisik, tapi dapat berupa kekerasan secara psikis.

\section{B. Kekerasan Dalam Rumah Tangga}

Kekerasan dalam rumah tangga dapat diartikan sebagai kekerasan yang terjadi dalam lingkup rumah tangga atau dalam suatu keluarga, dilakukan oleh salah seorang anggota keluarga terhadap anggota keluarga lainnya. Termasuk di dalamnya pola perilaku yang melibatkan fisik, seksual, ekonomi, dan emosional baik salah satu bagian tersebut ataupun kombinasinya (Jackson. edt, 2007; 1). Karena mayoritas korban adalah perempuan, KDRT disebut juga sebagai “kejahatan oleh laki-laki”, meski lingkup korbannya tidak terbatas hanya pada perempuan saja.

Secara sosiologis, definisi kekerasan dalam rumah tangga (domestic violence) cukup luas. Anak atau orang dewasa dapat menjadi korban dari orang yang lebih dewasa; anak dapat tersakiti secara fisik, psikologis, atau seksual oleh orang tua, kerabat, atau saudara kandung; gay atau lesbian yang disakiti oleh pasangannya; termasuk kekerasan atau perkosaan dalam pacaran (dating violence) juga dapat dikategorikan dalam KDRT (Parke, 2007; 404-408).

National Domestic Violence Hotline (NDVH) pada tahun 2007 mendefinisikan bahwa: 1), kekerasan domestik atau kekerasan dalam rumah tangga adalah suatu pola perilaku yang terdapat dalam semua hubungan dimana di dalamnya terdapat penggunaan kekerasan atau upaya pengendalian terhadap pasangan intimnya; 2), Tindakan atau perlakuan sewenangwenang secara fisik, seksual, emosional, ekonomi atau psikologis yang kemudian hal tersebut dapat mempengaruhi orang 
lain, termasuk didalamnya tindakan menakut-nakuti, intimidasi, terror, manipulasi, mempermalukan, menyakiti, menyalahkan, melukai atau mengancam akan melukai seseorang; 3), kekerasan domestik dapat terjadi pada siapa saja, ras apa saja, orientasi seksual, agama, ataupun gender. Ini dapat terjadi pada pasangan yang telah menikah, (samanleven), atau dalam masa pacaran. Kekerasan dalam rumah tangga mempengaruhi orang-orang dari semua latar belakang sosioekonomi dan tingkat pendidikan (Davis, 2008; 1).

Definisi NVDH mungkin membingungkan, untuk itu konsep Chalk dan King (1998) tentang ketidaksetaraan kekuasaan dan kendali cukup menarik untuk dibahas. Meski konsep ini tidak khusus membahas penyebab kekerasan dalam rumah tangga (Davis, 2008; 1).

Definisi yang lebih khusus dapat dilihat pada Pasal 1 Undang-undang nomor 23 tahun 2004, karena mendefinisikan keluarga sesuai yang dipahami oleh masyarakat Indonesia.

Dalam bahasan kekerasan dalam rumah tangga, terdapat istilah battered women syndrome. Walker (1979) mengistilahkan derita perempuan mengalami kekerasan tanpa memperoleh jalan keluar dari derita tersebut (termasuk akibat KDRT) sebagai battered women syndrome (bwp). Menurut Walker, kekerasan dalam hubungan battered tersebut tidak menunjukkan gejala yang konstan, melainkan seperti lingkaran ataupun gelombang, dimana terdapat puncakpuncak kekerasan dan periode-periode tenang. Kesewenangan tergantung pada suasana hati atau perasaan, sehingga penyiksaan atau kekerasan bersifat episodik dan tidak terduga, dimana dapat terjadi pada saat "normal” atau bahkan saat bermesraan.

Walker menggambarkan tiga pola umum dalam hubungan penuh siksa tersebut: 1, permasalahan sepele dapat memicu puncak kemarahan; 2, ledakan kekerasan, dan; 3, periode tenang setelah badai, dimana permintaan maaf dan janji membuat perempuan mengabaikan keseriusan permasalahan yang dihadapinya (Boyd, 2004; 41). Tiga pola ini menurut Walker berbentuk lingkaran dan terus berulang, sehingga korban (dalam hal ini perempuan) bahkan dapat menerima atau memaklumi siksaan yang mereka alami sebagai suatu kewajaran ataupun bentuk "hukuman" yang pantas mereka terima. Namun pada saat lain, battered women syndrome memiliki potensi untuk " meledak", bila 
akumulasi pendaman derita tersebut telah mencapai puncaknya. Hal ini yang menjadi rasionalisasi bila kemudian ada perempuan atau ibu rumah tangga melakukan kekerasan terhadap anggota keluarga atau bahkan suaminya.

Merujuk pada pengertian kekerasan dalam konteks rumah tangga di atas, kekerasan dalam rumah tangga dapat berupa penganiayaan secara fisik yang dapat menyebabkan cedera, cacat, hingga kematian. Pembatasan secara sosial seperti pelarangan atau pembatasan bersosialisasi, pembatasan pergaulan, dan lain sebagainya. Kekerasan secara ekonomi dapat berupa perampasan atau penguasaan hasil-hasil ekonomi, pembatasan akses ekonomi dan lain sebagainya. Kekerasan secara mental dapat berupa ancaman, mematamatai, merusak barang atau menyakiti hewan atau tanaman milik korban, dan lain sebagainya. Kekerasan dalam rumah tangga pada tulisan ini dibatasi pada konteks kekerasan secara fisik.

\section{Interaksi Simbolik}

Interaksi personal secara sederhana diartikan sebagai hubungan timbal-balik antara satu orang dengan orang lainnya. Interaksionis simbolik melihat interaksi sosial sebagai hal utama dalam sebuah proses komunikasi. Dimana seseorang merespon bukan pada apa yang pihak lain katakan atau lakukan, tetapi pada pemaknaan terhadap apa yang dia ucapkan atau tidak diucapkan (Blumer, 1978; xii). Simbolik disini diartikan sebagai sesuatu yang akan dimaknai, termasuk didalamnya bahasa verbal, gesture, keadaan lingkungan, dan lain sebagainya.

Blumer menggambarkan secara linear interaksi simbolik hubungan antara: stimulus-interpretasi-respon (Blumer, 1978; xii). Menurut Blumer, konsep utama dari interaksionisme simbolik adalah pada diri (the self). "Diri” memiliki dua aspek dasar yakni, diri sebagai proses, dan sebagai objek.

“Diri” sebagai proses merupakan pencerminan dari fakta bahwa manusia berinteraksi dengan dirinya sendiri. Pada interaksi dengan diri sendiri, manusia membuat indikasi-indikasi untuk dirinya, dan kemudian memberi respon atau tanggapan terhadap indikasi tersebut dengan menjadikannya sebagai indikasi diri (self indication). Ketika seseorang membuat indikasi diri, dia mengambil peran untuk menyusun indikasi atau dampak bagi dirinya dari sudut pandang orang lain, atau mengeneralisirnya. Hal ini akan terlihat saat seseorang 
memaknai situasi yang dihadapinya. Dia akan menafsirkan apa saja yang ia lihat dan rasakan, kemudian bertindak sesuai dengan prakiraan orang lain akan bertindak atau melakukan apa bila berada pada posisinya (Athens 1980; 15).

Fase kedua dalam interpretasi situasi adalah pengambilan keputusan. Di sini aktor memutuskan hal yang dianggap layak dilakukan dalam situasi yang dihadapi. Meski demikian, ia masih dapat mendefinisi ulang situasi yang dihadapinya sebelum melaksanakan rencananya. Jika ia membuat definisi baru, ia berkemungkinan akan mengambil keputusan baru (Athens 1980; 16).

Aspek yang kedua adalah diri sebagai “objek”, melihat pada fakta bahwa manusia memiliki konsepsi atau gambaran terhadap diri sendiri sebagai "gambaran diri” (self image). Gambaran diri dibangun dengan melihat pada dirinya sendiri, dan menilai apa yang dilihatnya. Dia dapat tidak secara langsung melihat atau menilai diri sendiri, tapi dengan cara tidak langsung menggunakan sudut pandang orang lain, terutama orang terdekat seperti keluarga, teman karib, kelompok acuan atau peer group (Athens 1980; 17).
Sehingga suatu tindakan individu dapat dipahami bukan sebagai suatu yang terjadi dengan serta merta, karena ketidaksengajaan atau bawaan sejak lahir, melainkan telah melewati beberapa proses dan pertimbangan, dan memiliki motivnya tersendiri, dan bahkan berasal dari gambaran yang ada di sekitarnya (Blumer, 2004: 59).

Dalam memahami kekerasan dikaitkan dengan penyimpangan sekunder, interaksionis simbolik melihat bahwa ketika menghadapi suatu situasi masalah dengan menjadikan kejahatan (kekerasan) sebagai resolusi, maka penyimpangan kemudian akan menjadi hal yang biasa, dan kebiasaan atau dapat diterima. Hal ini memberikan penjelasan kepada kita tentang gaya hidup pelaku kejahatan yang menjadikan kekerasan sebagai jalan singkat bagi penyelesaian permasalahan mereka (Walters, 2002; 12).

Pendekatan ini dapat menjelaskan hapir semua fenomena kekerasan yang muncul dalam interaksi interpersonal, kecuali untuk kekerasan yang melibatkan gangguan mental, atau kekerasan yang dilakukan terkait profesi. 
Pembahasan

Bahasan terkait permasalahan kekerasan dalam rumah tangga telah memasuki masa hampir empat dekade. Namun banyak diantara masyarakat kita belum menganggapnya sabagai suatu permasalahan yang penting. Kalaupun ada hanya sebatas sebagai urusan urusan pribadi, dan orang lain tidak perlu ikut mencampurinya.

Kalangan interaksionis memandang kekerasan dalam rumah tangga sebagai dampak dari ketidaklancaran komunikasi dalam suatu relasi. Hal ini terlihat pada adanya fakta bahwa kekerasan dalam rumah tangga yang terjadi umumnya diawali dengan pertengkaran, teriakan dibalas teriakan, bahkan teriakan yang dibalas dengan diam atau senyumanpun dapat ditafsirkan beragam seperti: sebagai bentuk ketidakpedulian, anggap remeh, hingga penghinaan. Hal-hal tersebut kemudian dapat memicu terjadinya kekerasan.

Sebagai hasil dari proses komunikasi dalam suatu interaksi interpersonal, kekerasan dalam rumah tangga merupakan bentuk dari penafsiran yang berbeda dari aktor (para pihak) terhadap situasi yang mereka hadapi. Penafsiran yang berbeda ini akan terus memuncak bila para aktor bertahan dengan penafsirannya masing-masing. Selanjutnya, bila aktor menafsirkan situasi yang dihadapinya sebagi ancaman baginya, atau merasa bahwa situasi yang dihadapi hanya dapat diatasi atau diakhiri dengan kekerasan, dan dia berada pada posisi lebih menguntungkan, maka kekerasan sangat mungkin akan terjadi.

Ketidaksetaraan dalam bahasan ini tidak persis serupa dengan pemahaman umum tentang ketidaksetaraan relasi gender dunia patriarkhi dalam pandangan feminisme. Dimana ketidaksetaraan gender dalam pandangan feminis merupakan suatu hal yang dibentuk, disosialisasikan, dan bahkan dilestarikan oleh laki-laki terhadap makhluk yang bukan laki-laki.

Ketidaksetaraan dalam relasi yang dimaksud dalam tulisan ini lebih terkait pada adanya penafsiran atau pemahaman akan kekuatan atau kekuasaan lebih yang dimiliki oleh salah satu pihak dibanding pihak lainnya dalam interaksi tersebut. Adanya pemahaman akan kekuatan atau kekuasaan yang tidak berimbang ini kemudian memunculkan situasi tidak setara dalam suatu interaksi. Meski memang tidak dapat dikesampingkan adanya peran nilai yang memposisikan 
hegemoni laki-laki dibanding perempuan dalam tercetusnya kekerasan dalam rumah tangga disebagian besar masyarakat kita. Anak, atau istri dianggap sebagai “milik” suami atau ayah, kemudian dimaknai sebagai “sesuatu” yang boleh diakukan apa saja oleh si pemilik. Tetapi dalam bahasan tulisan ini, ketidaksetaraan dalam relasi lebih bersifat situasional, dan tidak selalu berbasis gender.

Kesadaran memiliki kekuatan atau kekuasaan yang lebih dibanding pihak lain ini diperoleh aktor ketika ia telah menafsirkan situasi yang dihadapinya, menghitung apa yang dimiliki atau tidak dimiliki oleh dirinya atau mereka yang terlibat dalam interaksi tersebut. Misalnya, bila ia memiliki sesuatu yang dipahaminya dapat digunakan sebagai senjata, atau adanya dukungan dari pihak ketiga, maka ia memiliki potensi yang lebih besar akan melakukan kekerasan terlebih dahulu (pencetus kekerasan).

Kesadaran bahwa merasa lebih kuat, atau posisi lebih tinggi ini juga dapat menjelaskan alasan mengapa para perempuan yang mengalami battered women syndrome cendrung melakukan kekerasan kepada anak, pembantu, ataupun orang tuanya yang dianggap berposisi lebih rendah. Bilapun dilakukan terhadap suami atau laki-laki yang dianggap sebagai sumber penderitaannya, umumnya dilakukan bila ia bersenjata, dan atau si laki-laki tidak sadarkan diri.

Interksionis simbolik sendiri melihat bahwa korban bukanlah selalu berasal dari “orang yang tidak berdaya”, melainkan sebagai aktor yang berada pada posisi "kurang beruntung”. Hal ini didasari pada adanya andil korban terhadap terjadinya kekerasan. Korban tidak jarang dianggap memprovokasi pelaku untuk melakukan kekerasan. Jadi, sangat tergantung pada kesempatan siapa yang pada akhirnya menjadi korban atau pelaku (Kusumah, 1982; 32).

Guna mencegah tercetusnya kekerasan, sangat diharapkan adanya peran dan kepedulian pihak ketiga, yaitu mereka yang menjadi "penonton” dalam suatu interaksi. Pihak ketiga ini dapat berasal dari keluarga, tetangga, masyarakat, tokoh masyarakat, atau aparat berwenang. Keterlibatan pihak ketiga ini diharapkan bukan hanya sebagai mediator, tetapi juga dapat merubah persepsi para aktor terhadap situasi apa yang mereka hadapi. Dimana kehadiran pihak ketiga harus dapat merubah ketidakseimbangan menjadi relasi lebih seimbang. Sehingga pihak 
yang merasa telah berada pada posisi dominan mengambil keputusan baru (rejudgment) atau mengurungkan keputusannya semula.

\section{Kesimpulan}

Kekerasan dalam rumah tangga selain dapat menimbulkan derita secara fisik, tetapi juga mental kepada anggota keluarga tersebut, dan yang menjadi korban utama adalah perempuan dan anak.

Bukan menyederhanakan permasalahan yang ada, tetapi interaksionis simbolik umumnya tidak melihat jauh lebih dalam pada akar mula terjadinya kekerasan dalam rumah tangga seperti aliran pemikiran lainnya. Melainkan pada dinamika yang terjadi dalam interaksi hingga saat tercetusnya kekerasan. Sehingga pendekatan interaksionis simbolik dinilai dapat menyajikan resolusi yang lebih sederhana dalam menjelaskan dan menyelesaikan permasalahan terjadinya kekerasan interpersonal.

Tidak seperti perspektif lainnya, interaksionis simbolik tidak mencap suatu pihak sebagai bersalah atau pihak lainnya yang benar, sebagai pelaku atau korban. Bagi interaksionis, semua pihak yang berinteraksi dalam suatu relasi berpotensi menjadi pelaku ataupun korban kekerasan, baik itu para aktor, maupun pengamat atau penonton.

Peran "penonton” atau pihak ketiga menjadi penting guna merubah persepsi para aktor terhadap situasi yang mereka hadapi hingga tidak tercetus kekerasan. Sehingga sangat diperlukan kesediaan pihak ketiga "ikut campur” dalam menggeser ketidakseimbangan relasi sehingga para aktor yang terlibat setidaknya mendefinisi ulang situasi yang mereka hadapi, dan membuat rencana dan keputusan baru.

\section{Referensi}

Appel, K Jonathan and Dohee KimAppel. "Child Maltreatment And Domestic Violence: Human Services Issues". Journal of Health and Human Services Administration, Vol. 29, No. 2 (FALL 2006), pp. 228-244. SPAEF. Www.jstor.org/stable/25790689. Accessed: 05-10-2017 04:26.

Arendt, Hannah. 1970. On Violence. San Diego, New York, London; A Harvest Harcourt Brace Jovanovich.

Arthur, Christine and Roger Clark. "Determinants Of Domestic Violence: A Cross-National Study". International Journal of Sociology of the Family, Vol. 35, No. 2 (Autumn 2009), pp. 147-167. International Journals.

Athens, Lonnie H. 1980. Violent Criminal Act and Actors A Symbolic Interactionist Study. 
Boston, London and Henley: Routledge \& Kegan Paul. www.jstor.org/stable/23070721.

Accessed: 05-10-2017 04:25.

Blumer, Herbert, 2004. George Herbert Mead and Human Conduct. Walnut Creek, Lanbam, New York, Toronto, Oxford: Altmira Press A Division Of Rowman \& Littlefield Publishers, Inc.

Boyd, Nancy Kaser. 2004. "Battered Woman Syndrome: Clinical Features, Evaluation, and Expert Testimony”. B. J. Cling (edt). Sexualized Violence against Women and Children A Psychology And Law Perspective. New York; The Guilford Press.

Davis, Richard L., 2008. Domestic Violence : Intervention, Prevention, Policies, And Solutions. New York: CRC Press, Taylor \& Francis Group.

Clausewitz, Schmitt. "Schmitt's Challenge". James Dodd [edt]. 2009.Violence and Phenomenology. New York, London: Routledge Taylor \& Francis Group.

Gelles, J. Richard. "Family Violence", Annual Review of Sociology, Vol. 11 (1985), pp. 347-367. Annual Reviews, www.jstor.org/stable/2083298.

Accessed: 11-10-2017 19:41.

Gosita, Arif. 1993. Masalah Korban Kejahatan; Kumpulan Karangan. Jakarta: Akademika Pressindo.

Herrenkohl, Todd I., Eugene Aisenberg., 2011. James Herbert Williams., Jeffrey M. Jenson [editor]. Violence In Context Current Evidence on Risk, Protection, and Prevention. New York; Oxford University.

Jackson, Nicky Ali. 2007. Encyclopedia of Domestic Violence. New York,
London: Routledge Taylor \& Francis Group.

Kodir, Faqihuddin Abdul., Mukarnawati, Ummu Azizah. 2008. Referensi Bagi Hakim Peradilan Agama Tentang Kekerasan Dalam Rumah Tangga. Jakarta: Komnas Perempuan.

Latif, Syahrul Akmal., Fakhri Usmita., dan Riky Novarizal. 2017. Tren Kejahatan di Pekanbaru 20122016. Pekanbaru: Lembaga Penelitian Universitas Islam Riau.

Walters, Glenn, D. 2002. Criminal Belief Systems: An Integrated-Interactive Theory Of Lifestyles. Westport, Connecticut, London: Praeger. 